ORIENTAL JOURNAL OF CHEMISTRY

An International Open Free Access, Peer Reviewed Research Journal

www.orientjchem.org
ISSN: 0970-020 X

CODEN: OJCHEG

2015, Vol. 31, No. (1):

Pg. 271-276

\title{
Removal of Methylene Blue Dye from Aqueous Solutions by Elaeagnusan Gastifolial as an Adsorbent
}

\author{
REZVAN ZEYNOLABEDIN ${ }^{1}$, AZAM MARJANI ${ }^{1}$, AREF SHOKRI ${ }^{2}$, \\ MAJID SAGHI ${ }^{3}$ and MOHAMMAD HOSEIN BIGTAN ${ }^{4}$ \\ ${ }^{1}$ Department of Chemistry, Islamic Azad University, Arak Branch, Arak, Iran \\ ${ }^{2}$ Young researcher and elite, Arak Branch, Islamic Azad University, Arak, Iran. \\ ${ }^{3}$ Department of Chemistry, Faculty of science, Quchan Branch, Islamic Azad University, Quchan, Iran. \\ ${ }^{4}$ Department of Chemistry, Faculty of science, Arak Branch, Islamic Azad University, Arak, Iran. \\ ${ }^{*}$ Corresponding author E-mail: a-marjani@iau-arak.ac.ir
}

http://dx.doi.org/10.13005/ojc/310130

(Received: December 05, 2014; Accepted: January 15, 2015)

\begin{abstract}
Batch experiments were carried out for the sorption of methylene blue onto elaeagnusan gastifolial particles. The operating variables studied were initial solution $\mathrm{pH}$, contact time, adsorbent dosage and temperature. Equilibrium data were fitted to Freundlich and Langmuir isotherm equation and the equilibrium data were found to well represented by Langmuir isotherm equation. Various thermodynamic parameters such as enthalpy of sorption $\left(\Delta \mathrm{H}^{\circ}\right)$, free energy change $\left(\Delta \mathrm{G}^{\circ}\right)$ and entropy $\left(\Delta S^{\circ}\right)$ were estimated. The positive value of $\Delta \mathrm{H}^{\circ}$ and negative value of $\Delta \mathrm{G}^{\circ}$ shows the sorption process is endothermic and spontaneous. The positive value of entropy $\Delta S^{\circ}$ shows the increased randomness at the solid-liquid interface during the sorption of dye ions onto elaeagnusan gastifolial particles.
\end{abstract}

Key words: Methylene blue, Separation, Simulation, Thermodynamic parameters.

\section{INTRODUCTION}

The removal of color from dye bearing effluents is one of the major problems due to the difficulty in treating such wastewaters by conventional treatment methods. The most commonly used methods for color removal are biological oxidation and chemical precipitation.
However, these processes are effective and economic only in the case where the solute concentrations are relatively high. Currently sorption process is proved to be one of the effective and attractive processes for the treatment of these dye-bearing wastewaters ${ }^{1-5}$. Also this method will become inexpensive, if the sorbent material used is of inexpensive material and does not require any 
expensive additional pretreatment step. In the present study elaeagnusan gastifolial have been used as adsorbent for the removal of methylene blue from its aqueous solution. Methylene blue is selected as a model compound in order to evaluate the capacity of elaeagnusan gastifolial for the removal of dye (methylene blue) from its aqueous solutions.

Methylene blue has wider applications, which include coloring paper, temporary hair colorant, dyeing cottons, wools, coating for paper stock, etc. Though methylene blue is not strongly hazardous, it can cause some harmful effects. Acute exposure to methylene blue will found cause increased heart rate, vomiting, shock, Heinz body formation, cyanosis, jaundice, quadripelgia and tissue necrosis in humans. Previously several researchers had proved several low cost materials such as pear millet husk carbon ${ }^{6}$; Aspergillus niger ${ }^{7}$ rice husk ${ }^{8}$; hair ${ }^{8}$; cotton waste ${ }^{8}$; bark $^{8}$; perlite ${ }^{9}$; carbonized press mud $^{10}$; bagasse bottom ash ${ }^{10}$; raw kaolin ${ }^{11}$; pure kaolin ${ }^{11}$; calcined rawkaoline ${ }^{11}$; calcined pure kaoline ${ }^{11} ; \mathrm{NaOH}$ treated rawkaolin ${ }^{11}$; coir pith ${ }^{12}$; guava seeds activated carbon ${ }^{13}$; iron humate ${ }^{14}$; neem sawdust ${ }^{15}$; clay $^{16}$. In the present study elaeagnusan gastifolial have been used as an adsorbent for the removal of methylene blue from its aqueous solutions and the effect of initial solution $\mathrm{pH}$, contact time, adsorbent dosage and temperature on the amount of color removal have been investigated.

\section{MATERIALS AND METHODS}

The dye used in all the experiments was methylene blue, a basic (cationic) dye. The dye methylene blue was obtained from Sigma Chemical Co. (St. Louis, MO, USA). The chemical formula of methylene blue ${ }^{17}$.

Synthetic dye solutions were prepared by dissolving weighed amount methylene blue in $1 \mathrm{~L}$ of double distilled water. The $\mathrm{NaOH}$ and $\mathrm{HCl}$ solutions used for optimizing $\mathrm{pH}$ are obtained by Merck (Germany).

Elaeagnusan gastifolial used in this investigation were collected from a number of trees in many cities in Iran. They were washed repeatedly with distillated water to remove dust and soluble impurities, dried at room temperature for $24 \mathrm{~h}$, ground in mortar to a very fine powder and sieved through a $125 \mu \mathrm{m}$ copper sieve and stored in desiccators before use.

\section{RESULTS AND DISCUSSIONS}

\section{Effect of pH}

The effect of $\mathrm{pH}$ on the amount of color removal was analyzed over the $\mathrm{pH}$ range from 2 to 12. The $\mathrm{pH}$ was adjusted using $0.1 \mathrm{~N} \mathrm{NaOH}$ and $0.1 \mathrm{~N} \mathrm{HCl}$ solutions. In this study $30 \mathrm{~mL}$ of dye solution of $100 \mathrm{mg} / \mathrm{L}$ was agitated with $0.2 \mathrm{~g}$ of elaeagnusan gastifolial for $1 \mathrm{~h}$, which is more than sufficient to reach equilibrium. The samples were then centrifuged and the left out concentration in the supernatant solution were analyzed using UV Spectrophotometer by monitoring the absorbance changes at a wavelength of maximum absorbance (665 nm).

Dependence of dye adsorption on $\mathrm{pH}$ is shown in Fig. 1. Dye adsorption efficiency is affected by $\mathrm{pH}$ variation. The adsorption of methylene blue increased with an increase $\mathrm{pH}$. The optimum $\mathrm{pH}$ for the adsorption of methylene blue was found to be in the range 8-12. This can be explained with the electrostatic interaction of methylene blue (because of its cationic structure) with negatively charged surface of elaeagnusan gastifolial. Similar trends were observed for the adsorption of methylene blue onto $\mathrm{Fe}$ (III)/Cr(III) hydroxide ${ }^{18}$, malachite green onto agro-industry waste ${ }^{19}$, methylene blue onto various carbons ${ }^{20}$.

\section{Effects of contact time}

The effects of contact time in the range 560 min were studied using a constant concentration $(100 \mathrm{mg} / \mathrm{L}$ ) of dye solution, $\mathrm{pH} 8$ and a temperature of $25^{\circ} \mathrm{C}$. The percentage removal of the methylene blue as a function of contact time is shown in the Fig. 2. The percent dye removal increased with increased contact time. Maximum quantitative removal of methylene blue from an aqueous solution was obtained in 50 min contact time. Beyond 50 min, there was no increase in dye removal. This can be related to saturation of adsorbtion sites. 


\section{Effect of adsorbent dosage}

Fig. 3 shows the effect of adsorbent dosage on methylene blue adsorption onto elaeagnusan gastifolial. In order to investigate the effect of adsorbent dosage on the methylene blue adsorption onto elaeagnusan gastifolial, an initial dye concentration of $100 \mathrm{mg} / \mathrm{L}$ was selected. The range of adsorbent dosage was between 0.2 to 0.6 g. As can be seen from Fig. 3, when the adsorbent dosage increases, removal efficiency of methylene blue also increases. Adsorbent dosage was increased from 0.2 to $0.6 \mathrm{~g}$ as dye removal efficiency increased from 80 to $93 \%$. Similar results were reported for methylen blue adsorption by Posidonia oceanica $^{21}$.

\section{The effect of temperature}

The effect of temperature on the adsorption of methylene blue is shown in Fig. 4. The results showed that dye sorption capacity of elaeagnusan gastifolial increased with changing the temperature from 25 to $65^{\circ} \mathrm{C}$. Since the adsorption increased when temperature rose, this system was considered to be endothermic. In addition to, some researchers reported increased methylene blue removal with increasing temperature values ${ }^{22-24}$.

Adsorption enthalpy was measured using the method based on the Van, $\mathrm{t}$ Hoff plot. The values of $\Delta \mathrm{H}^{\circ}$ and $\Delta \mathrm{S}^{\circ}$ were calculated from the slops and intercepts of the linear variation of $\mathrm{In} \mathrm{K}_{\mathrm{c}}$ with reciprocal temperature, $1 / \mathrm{T}$ (Fig. 5), using the relation: $\ln \mathrm{K}_{\mathrm{c}}=\left(\Delta \mathrm{S}^{\circ} / \mathrm{R}\right)-\left(\Delta \mathrm{H}^{\circ} / \mathrm{RT}\right)$

Where $\Delta \mathrm{H}^{\circ}$ and $\Delta \mathrm{S}^{\circ}$ are the standard enthalpy and entropy changes of adsorption, respectively. The free energy of specific adsorption $\Delta \mathrm{G}^{\circ}$ is calculated using the equation:

$$
\Delta \mathrm{G}^{\circ}=\Delta \mathrm{H}^{\circ}-\mathrm{T} \Delta \mathrm{S}^{\circ}
$$

The values of $\Delta \mathrm{H}^{\circ}, \Delta \mathrm{S}^{\circ}$ and $\Delta \mathrm{G}^{\circ}$ were given in Table 1 for methylene blue biosorption on elaeagnusan gastifolial. The value of $\Delta \mathrm{H}^{\circ}=9.14 \mathrm{~kJ} /$ mol and $\Delta \mathrm{G}^{\circ}=-4.87 \mathrm{~kJ} / \mathrm{mol}$ at $25^{\circ} \mathrm{C}$ suggest that the sorption of methylene blue on elaeagnusan gastifolial is endothermic and a spontaneous process. The positive value of entropy " $\mathrm{S}$ ' shows the increased randomness at the solid-liquid interface during the sorption of dye ions onto elaeagnusan gastifolial particles.

\section{Adsorption isotherms}

The analysis and design of sorption process requires the relevant adsorption equilibria, which is the most important piece of information in understanding an adsorption process ${ }^{2}$. Sorption equilibria provide fundamental physiochemical data for evaluating the applicability of sorption process as an unit operation. The two most commonly used equilibrium relations are Freundlich and Langmuir ${ }^{25}$ isotherm equations. In the present investigation the equilibrium data were analyzed using the Freundlich and Langmuir isotherm expression given by equations (3) and (4), respectively:

Table 1: Thermodynamic parameters for the biosorption of methylene blue on elaeagnusan gastifolial

\begin{tabular}{lccc}
\hline Dye & $\Delta \mathrm{G}^{\circ}(\mathrm{kJ} / \mathrm{mol})$ & $\Delta \mathrm{H}^{\circ}(\mathrm{kJ} / \mathrm{mol})$ & $\Delta \mathbf{S}^{\circ}(\mathrm{kJ} / \mathrm{mol})$ \\
\hline methylene blue & -4.87 & 9.14 & 0.047 \\
\hline
\end{tabular}

Table 2: The constants of Langmuir and Freundlich isotherms for biosorption of methylene blue on elaeagnusan gastifolial

\begin{tabular}{lllllll}
\hline & \multicolumn{3}{c}{ Langmuir constants } & & \multicolumn{3}{c}{ Freundlich constants } \\
\cline { 1 - 3 } \cline { 5 - 7 } $\mathbf{q}_{\mathbf{m}}(\mathbf{m g} / \mathbf{g})$ & $\mathrm{K}_{\mathrm{l}}(\mathrm{L} / \mathrm{mg})$ & $\mathbf{R}^{2}$ & & $\mathrm{~K}_{\mathrm{f}}$ & $\mathbf{n}$ & $\mathbf{R}^{2}$ \\
\hline 17.24 & 1.813 & 0.9555 & & 10.233 & 2.236 & 0.7616 \\
\hline
\end{tabular}


Freundlich : $\mathrm{q}_{\mathrm{e}}=\mathrm{K}_{\mathrm{f}} \cdot \mathrm{C}_{\mathrm{e}}{ }^{1 / n}$

$$
\text { Langmuir } q_{\theta}=\frac{q_{m} \cdot K_{l} \cdot C_{e}}{1+K_{l} \cdot C_{e}}
$$

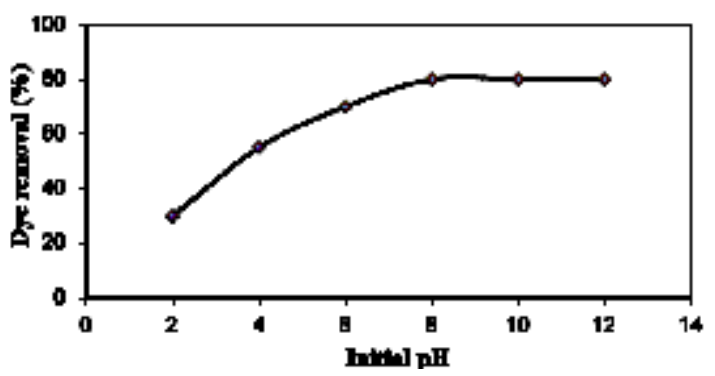

Fig. 1: The variation of the amount adsorbed with suspension $\mathrm{pH}$ at $25^{\circ} \mathrm{C}$ (sorption time: $1 \mathrm{hr}$; initial dye concentration: $100 \mathrm{mg} / \mathrm{L}$; mixing rate: 150 rpm; absorbent concentration: $0.2 \mathrm{~g} / 30 \mathrm{~mL}$ )

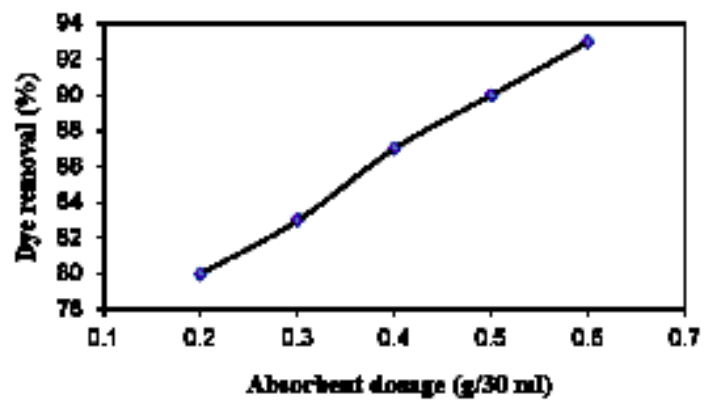

Fig. 3: Effect of adsorbent dosage on methylene blue adsorption onto elaeagnusan gastifolial at $25^{\circ} \mathrm{C}$ (initial dye concentration: $100 \mathrm{mg} / \mathrm{L}$, mixing rate: $150 \mathrm{rpm}, \mathrm{pH}=\mathbf{8 . 0}$ )

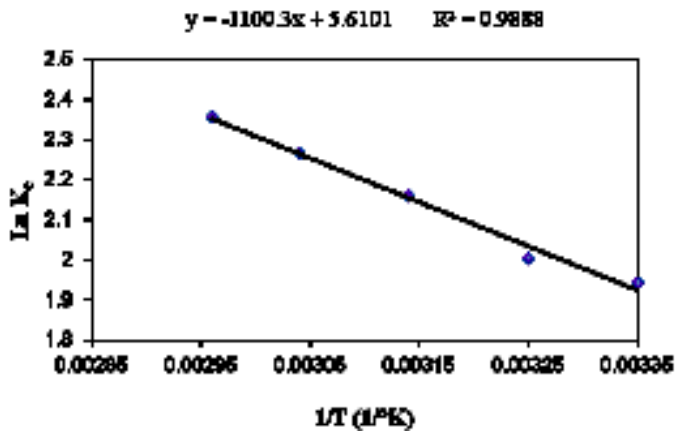

Fig. 5: Plot of In $K_{c}$ vs. 1/T for the methylene blue adsorption on elaeagnusan gastifolial (initial dye concentration: $100 \mathrm{mg} / \mathrm{L}$, mixing rate: $150 \mathrm{rpm}$; absorbent concentration: $0.2 \mathrm{~g} / 30 \mathrm{~mL}, \mathrm{pH}=\mathbf{8 . 0}$ ) where $K_{f}$ and $\mathrm{n}$ are Freundlich constants related to sorption capacity and sorption intensity of adsorbents, $q_{m}$ is the maximum sorption capacity of elaeagnusan gastifolial to uptake methylene blue

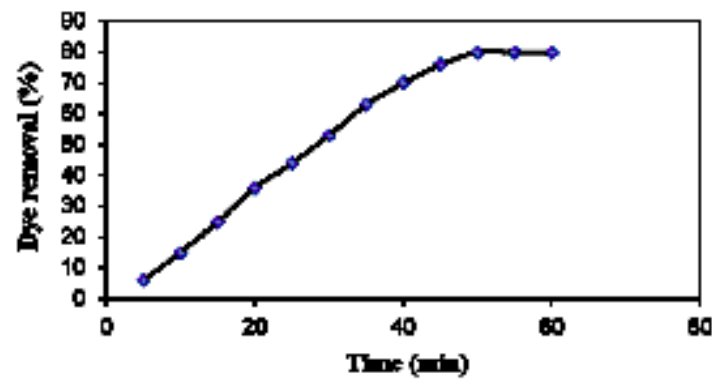

Fig. 2: Effect of contact time on adsorption of methylene blue from aqueous solution onto adsorbent at $25^{\circ} \mathrm{C}$ (initial dye concentration: $100 \mathrm{mg} / \mathrm{L}$; mixing rate: $150 \mathrm{rpm}$; absorbent concentration: $0.2 \mathrm{~g} / 30 \mathrm{~mL}, \mathrm{pH}=8.0$ )

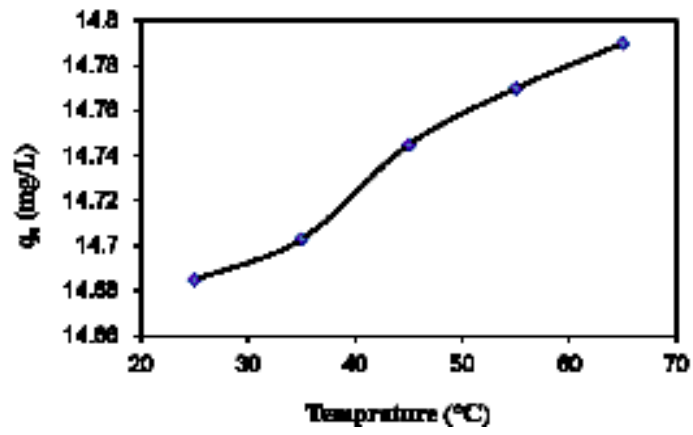

Fig. 4: Effect of temperature on methylene blue adsorption onto elaeagnusan gastifolial (initial dye concentration: $100 \mathrm{mg} / \mathrm{L}$, mixing rate: $150 \mathrm{rpm}$; absorbent concentration: $0.2 \mathrm{~g} / 30 \mathrm{~mL}, \mathrm{pH}=8.0$ )

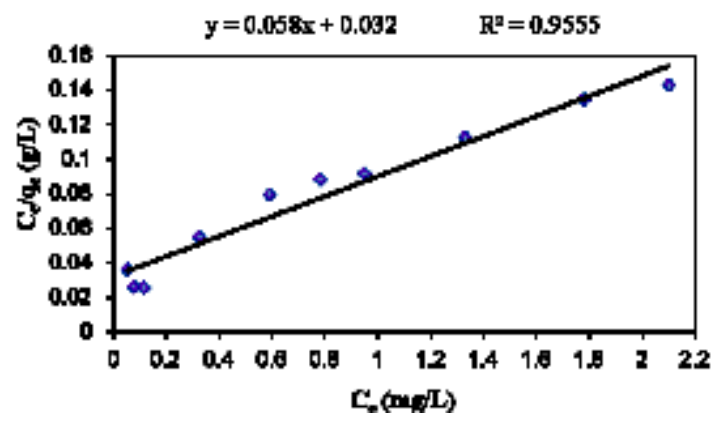

Fig. 6: Langmuir plot for sorption of methylene blue onto elaeagnusan gastifolial at $25^{\circ} \mathrm{C}$ (mixing rate: $150 \mathrm{rpm}$; absorbent concentration: $0.2 \mathrm{~g} / 30 \mathrm{~mL}, \mathrm{pH}=8.0$ ) 
(mg/g) and $K_{l}$ is the Langmuir constant related to the energy of adsorption $(\mathrm{L} / \mathrm{mg})$. The value of $n$ falling in the range of 1-10 indicates favorable sorption. The linearised form of Freundlich and Langmuir can be written as follows:

$$
\begin{aligned}
& \log q_{e}=\log K_{f}+1 / \mathrm{n} \cdot\left(\log C_{e}\right) \\
& \left.C_{e} / q_{e}=1 / K_{l} \cdot q_{m}\right)+C_{e} / q_{m}
\end{aligned}
$$

Thus the Freundlich constant $K_{f}$ and $n$ can be calculated from the intercept and slope of plot between $\log q_{e}$ and $\log C_{e}$. Similarly the Langmuir constants $q_{m}$ and $K_{l}$ were calculated from the slope of plot between $C_{e} / q_{e}$ versus $C_{e}$.

The Langmuir and Freundlich adsorption constants evaluated from the isotherms with the

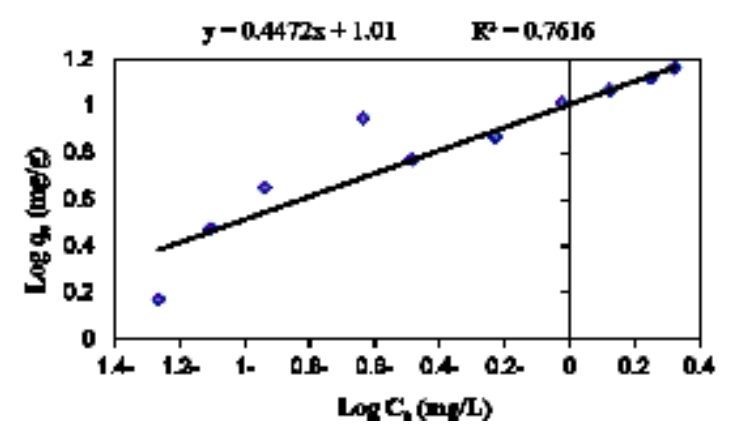

Fig. 7: Freundlich plot for sorption of methylene blue onto elaeagnusan gastifolial at $25^{\circ} \mathrm{C}$ (mixing rate: $150 \mathrm{rpm}$; absorbent concentration: $0.2 \mathrm{~g} / 30 \mathrm{~mL}, \mathrm{pH}=\mathbf{8 . 0}$ ) correlation coefficients were listed in Table 2 . It could be seen from Fig. 6 and Fig. 7 that the Langmuir isotherm gave better fits than the Freundlich isotherm. Based on the value of the correlation coefficient $\left(R^{2}>0.95\right)$ it could be seen that the behavior of methylene blue biosorption on to powdered leaf of elaeagnusan gastifolial is a Langmuir type isotherm.

\section{CONCLUSION}

The present study shows that the elaeagnusan gastifolial can be used as an adsorbent for the removal of methylene blue from aqueous solutions. The amount of dye sorbed was found to vary with initial solution $\mathrm{pH}$, contact time, adsorbent dose and temperature.

The amount of dye uptake $(\mathrm{mg} / \mathrm{g})$ was found to increase with increase in initial solution $\mathrm{pH}$, contact time, adsorbent dosage and solution temperature. Thermodynamic parameter shows that the process is endothermic and spontaneous. Equilibrium data were fitted well in Langmuir isotherm equation confirming the monolayer sorption capacity of methylene blue onto elaeagnusan gastifolial particles with a monolayer sorption capacity of $17.24 \mathrm{mg} / \mathrm{g}$.

\section{ACKNOWLEDGEMENTS}

The authors are grateful to Azad University of Arak for support. We also thank to Negin Moradi for her helpful suggestions.

\section{REFERENCES}

1. V.K. Gupta, I. Ali, and M.D. Suhas, Equilibrium uptake and sorption dynamics for the removal of a basic dye (basic red) using lowcost adsorbents, J. Colloid Interface Sci. 2003; 265, pp. 257-264.

2. Y.S. Ho and G. McKay, The kinetics of sorption of basic dyes from aqueous solutions by sphagnum moss peat, Can. J. Chem. Eng. 1998; 76, pp. 822-826.

3. G.M. Walker, L. Hansen, J.A. Hanna, and S.J. Allen, Kinetics of a reactive dye adsorption onto dolomite sorbents, Water Res. 2003,
37, pp. 2081-2089.

4. G. McKay, S.J. Allen, I.F. McConvey, and M.S. Otterburn, Transport process in the sorption of colored ions by peat particles, J. Colloid Interface Sci. 1981, 80(2), pp. 323-339.

5. G. McKay and S.J. Allen, Surface mass transfer process using peat as an adsorbent for dyestuffs, Can. J. Chem. Eng. 1980, 58, pp. 521-526.

6. B.S. Inbaraj, K. Selvarani, and N. Sulochana, Evaluation of a carbonaceous sorbent prepared from Pearl Millet Husk for its 
removal of basic dyes, J. Sci. Ind. Res. 2002, 61, pp. 971-978.

7. Y. Fu and T. Viraraghavan, Column studies for biosorption of dyes from aqueous solutions on immobilised Aspergillus niger fungal biomass, Water SA. 2003, 29(4), pp. 465-472.

8. G. McKay, J.F. Porter, and G.R. Prasad, The removal of basic dyes aqueous solution by adsorption on low-cost materials, Water Air Soil Pollut. 1999, 114, 423-438.

9. M. Dogan, M. Alkan, A. Turkyilmaz, and Y. Ozdemir, Kinetics and mechanism of removal of methylene blue by adsorption onto perlite, J. Hazard. Mater. 2004, 109, pp. 141-148.

10. K.V. Kumar, Adsorption isotherms for basic dyes onto low cot adsorbents, Res. J. Chem. Environ. 2002, 6, pp. 61-65.

11. D. Gosh and G. Bhattacharya, Adsorption of methylene blue on kaolinite, Appl. Clay Sci. 2002, 20, 295-300.

12. C. Namasiayam, M.D. Kumar, K. Selvi, R.A. Begum, T. Vanathi, and R.T. Yamuna, 'Waste' coir pith-a potential biomass for the treatment of dyeing wastewaters, Biomass Bioenergy 2001, 21, pp. 477-483.

13. I.A. Rahman and B. Saad, Utilization of guava seeds as a source of activated carbon for removal of methylene blue from aqueous solution, Malays. J. Chem. 2003, 5, pp. 8-14.

14. P. JanoÇs, Sorption of basic dyes onto iron humate, Environ. Sci. Technol. 2003, 37, pp. 5792-5798.

15. S.D. Khattri and M.K. Singh, Color removal from synthetic dye wastewater using a biosorbent, Water Air Soil Pollut. 2000, 120, pp. 283-294.

16. A. Gürses, S. Karaca, C'. DogØar, R. Bayrak, A. Acikyildiz, and M. Yalcin, Determination of adsorptive properties of clay/water system: methylene blue sorption, J. Colloid Interface Sci. 2004, 269, pp. 310-314.

17. S. Wang, Z.H. Zhu, A. Coomes, F.
Haghseresht, and G.Q. Lu, The physical and surface chemical characteristics of activated carbons and the adsorption of methylene blue from waste water, J. Colloid Interface Sci. 2005, 284, pp. 440-444.

18. C. Namasivayam and S. Sumithra, Removal of direct red $12 \mathrm{~B}$ and methylene blue from water by adsorption onto $\mathrm{Fe}(\mathrm{III}) / \mathrm{Cr}(\mathrm{III})$ hydroxide, an industrial solid waste, J. Hazard. Mater. 2005, B92, pp. 263-274.

19. V.K. Garg, M. Amita, R. Kumar, and R. Gupta, Basic dye(methylene blue) removal from simulated wastewater by adsorption using Indian rosewood sawdust: a timber industry waste, Dyes and Pigments 2004, 63, 243250.

20. N. Kannan and M.M. Sundaram, Kinetics and mechanism of removal of methylene blue by adsorption on various carbons - a comparative study, Dyes and Pigments 2001, 51, pp. 25-40.

21. M.C. Ncibi, B. Mahjoub, and M. Seffen, Kinetic and equilibrium studies of methylene blue biosorption by Posidonia oceanica (L.) fibres, J. Hazard. Mater. 2007, 139, pp. 280-285.

22. M. DogØan, M. Alkan, A. Tu“rkyilmaz, and Y. O" zdemir, Kinetics and mechanism of removal of methylene blue by adsorption onto perlite, J. Hazard. Mater. B 2004, 109, pp. 141-148.

23. K.G. Bhattacharyya and A. Sharma, Kinetics and thermodynamics of methylene blue adsorption on Neem (Azadirachta indica) leaf powder, Dyes and Pigments 2005, 65, pp. 51-59.

24. S. Wang, L. Li, H. Wu, and Z.H. Zhu, Unburned carbon as a low-cost adsorbent for treatment of methylene blue-containing wastewater, J. Colloid Interface Sci. 2005, 292, pp. 336343.

25. I. Langmuir, The constitution and fundamental properties of solids and liquids, J. Am. Chem. Soc. 1916, 38, pp. 2221-2295. 